\title{
Roles of ASYMMETRIC LEAVES2 (AS2) and Nucleolar Proteins in the Adaxial-Abaxial Polarity Specification at the Perinucleolar Region in Arabidopsis
}

\author{
Hidekazu Iwakawa $^{1}$, Hiro Takahashi ${ }^{2} \mathbb{D}$, Yasunori Machida ${ }^{3, *}$ and Chiyoko Machida ${ }^{1, *}$ \\ 1 Graduate School of Bioscience and Biotechnology, Chubu University, 1200, Matsumoto-cho, Kasugai, \\ Aichi 487-8501, Japan; iwakawa@isc.chubu.ac.jp \\ 2 Graduate School of Medical Sciences, Kanazawa University, Kakuma-machi, Kanazawa, \\ Ishikawa 920-1192, Japan; takahasi@p.kanazawa-u.ac.jp \\ 3 Division of Biological Science, Graduate School of Science, Nagoya University, Furo-cho, Chikusa-ku, \\ Nagoya, Aichi 464-8602, Japan \\ * Correspondence: yas@bio.nagoya-u.ac.jp (Y.M.); cmachida@isc.chubu.ac.jp (C.M.); \\ Tel.: +81-52-789-2502 (Y.M.); +81-568-51-6276 (C.M.)
}

Received: 21 August 2020; Accepted: 29 September 2020; Published: 3 October 2020

\begin{abstract}
Leaves of Arabidopsis develop from a shoot apical meristem grow along three (proximal-distal, adaxial-abaxial, and medial-lateral) axes and form a flat symmetric architecture. ASYMMETRIC LEAVES2 (AS2), a key regulator for leaf adaxial-abaxial partitioning, encodes a plant-specific nuclear protein and directly represses the abaxial-determining gene ETTIN/AUXIN RESPONSE FACTOR3 (ETT/ARF3). How AS2 could act as a critical regulator, however, has yet to be demonstrated, although it might play an epigenetic role. Here, we summarize the current understandings of the genetic, molecular, and cellular functions of AS2. A characteristic genetic feature of AS2 is the presence of a number of (about 60) modifier genes, mutations of which enhance the leaf abnormalities of as2. Although genes for proteins that are involved in diverse cellular processes are known as modifiers, it has recently become clear that many modifier proteins, such as NUCLEOLIN1 (NUC1) and RNA HELICASE10 (RH10), are localized in the nucleolus. Some modifiers including ribosomal proteins are also members of the small subunit processome (SSUP). In addition, AS2 forms perinucleolar bodies partially colocalizing with chromocenters that include the condensed inactive 45S ribosomal RNA genes. AS2 participates in maintaining CpG methylation in specific exons of ETT/ARF3. NUC1 and RH10 genes are also involved in maintaining the CpG methylation levels and repressing ETT/ARF3 transcript levels. AS2 and nucleolus-localizing modifiers might cooperatively repress ETT/ARF3 to develop symmetric flat leaves. These results raise the possibility of a nucleolus-related epigenetic repression system operating for developmental genes unique to plants and predict that AS2 could be a molecule with novel functions that cannot be explained by the conventional concept of transcription factors.
\end{abstract}

Keywords: ASYMMETRIC LEAVES2; AS2/LOB domain; adaxial-abaxial polarity; ETTIN/AUXIN RESPONSE FACTOR3 (ETT/ARF3); AS2 body; nucleolus; gene body methylation; ribosomal DNA (rDNA)

\section{Leaf Developments in Arabidopsis}

Leaves develop from a shoot apical meristem (SAM) as lateral organs along three axes: proximal-distal, adaxial-abaxial, and medial-lateral [1-7]. Initially, groups of cells on the peripheral 
zone of the SAM are specified in leaf primordia (P0, Figure 1) and grow along the proximal-distal axis (P1). Then, adaxial-abaxial structures are differentiated (P2). Subsequently, cells proliferate along the medial-lateral axis leading to flat and symmetric leaves (Figure 1) $[2,3,8]$. To date, numerous genes involved in adaxial-abaxial determination have been reported in Arabidopsis thaliana [2,9]. The ASYMMETRIC LEAVES2 (AS2) and ASYMMETRIC LEAVES1 (AS1), which encode a protein with the plant-specific AS2/LOB domain and a protein with the MYB (SANT) domain, respectively, were originally identified as factors involved in symmetric leaf lamina formation [10-13]. Recent studies have revealed, however, that AS2 and AS1 regulate proper morphology along all three axes of leaves. The Rough Sheath2 (RS2) gene of maize, an ortholog of PHANTASTICA (PHAN) of Antirrhinum majus and $A S 1$ of Arabidopsis, is involved in the proximal-distal patterning of maize leaves through the repression of class 1 KNOX genes $[10,14,15]$. The PHAN gene is involved in growth and the adaxial-abaxial determination of lateral organs. In addition, its activity is required early in the growth of leaves in the direction of the proximal-distal axis [16,17]. The ectopic expression of class 1 Knotted1-like homeobox (KNOX) genes in as 1 and as 2 mutant plants results in reductions in the growth of leaf blades and petioles in Arabidopsis, and these phenotypes are suppressed by mutations of the class 1 KNOX genes, brevipedicellus (bp), knat2, and knat6. These results indicate that the AS1 and AS2 genes of Arabidopsis are involved in the establishment of the proximal-distal axis through the repression of the class 1 KNOX genes [18]. In addition, the formation of shorter petioles and leaf blades in as 1 and as 2 is due to repression of gibberellin-synthetic genes by the upregulation of BP/KNAT1, KNAT2, and KNAT6 [18]. AS1, acting together with AS2, directly represses the expression of the BP and KNAT2 genes [19]. In this review, we focus on the establishment of leaf adaxial-abaxial polarity.

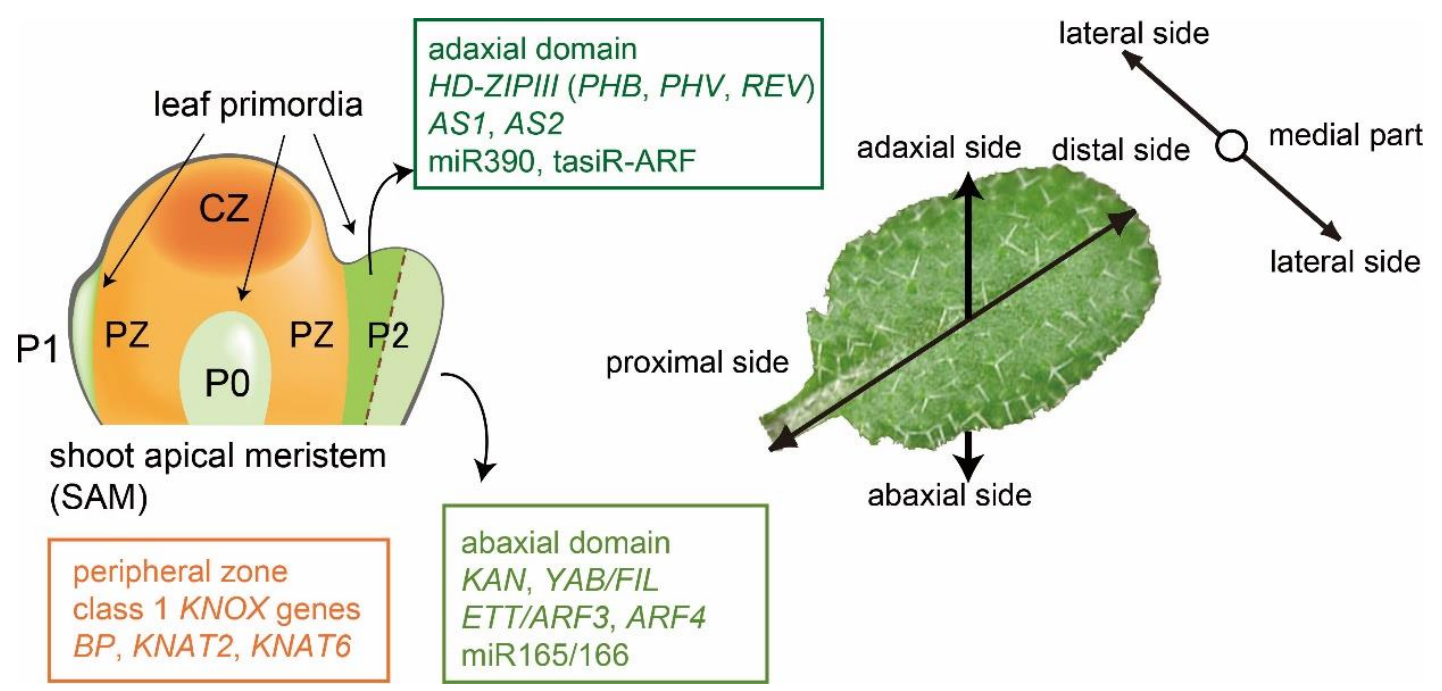

Figure 1. The leaf structure develops along three axes. Developmental compartments in the shoot apex around the apical meristem and the three structural leaf axes are schematically shown on the left and right sides, respectively (see details in text). CZ, central zone; $\mathrm{PZ}$, peripheral zone; $\mathrm{p} 0$, primordium 0 ; p1, primordium 1; p2, primordium 2. Schematic representations are modified from ref. [2].

The PHABULOSA (PHB), PHAVOLUTA (PHV), and REVOLUTA (REV) genes encode class III homeodomain-leucine zipper (HD-ZIPIII) proteins, which determine adaxial cell fate [20-22]. Small RNAs play critical roles in specifying adaxial-abaxial polarity [23,24]. Micro RNAs miR165/166 promote the degradation of $H D$-ZIPIII transcripts in the abaxial domain, which results in the accumulation of HD-ZIPIII in the adaxial domain [24]. Members of the KANADI (KAN) gene family, which encode proteins with the GARP domain, determine abaxial cell fate [22,25]. The Arabidopsis genome contains six $Y A B B Y$ genes, which encode transcription factors with a zinc-finger domain and an HMG-related domain with a helix-loop-helix structure. The three YABBY genes, FILAMENTOUS FLOWER (FIL), YABBY3 (YAB3), and YAB2 are expressed in the abaxial domains of all leaf-derived 
organs, including cotyledons, leaves, and floral organs [26-30]. Furthermore, genetic analyses have shown that four YABBY genes (FIL, YAB3, YAB2, YAB5) govern embryo patterning and the growth of leaf lamina along the abaxial-adaxial boundary [30].

ETTIN/AUXIN RESPONSE FACTOR3 (ETT/ARF3) and ARF4 also specify both abaxial cell fate and the lateral growth of leaf lamina [31]. Transcripts of both ETT/ARF3 and ARF4 are specifically degraded by the small RNA tasiR-ARF, which is generated through a miR390 pathway in the presumptive adaxial domain and contributes to the determination of the adaxial cell fate [23]. Because a loss of adaxial-abaxial polarity is often accompanied by a defect of leaf lamina expansion, it is suggested that the lateral growth of the lamina could be related to the determination of adaxial-abaxial identity, as previously proposed [2,32].

\section{Roles of AS2-AS1 in the Development of Leaf Polarity}

As described above, AS2 and AS1 proteins, which have AS2/LOB and R2R3 MYB (SANT) domains, respectively (Figure 2a), are identified by a yeast two-hybrid system, pull-down and gel-shift assays, and subcellular co-localization analyses. Because of their nature, these experiments indicate that AS2 and AS1 are physically associated with each other in vitro [19,33-36], implying also that they form a protein complex in the nucleus. Transcripts of AS2 and AS1 genes accumulate throughout the entire leaf primordia at early stages, in which the AS2-AS1 complex might be formed, but the accumulation patterns change as the leaves develop [37]. AS2 transcripts are detected in the adaxial domain, while AS1 transcripts are detected in the central region between the adaxial and abaxial domains of leaf primordia and the vasculature regions in more developed leaf primordia $[10,37]$. The plant-specific AS2/LOB domain includes a CXXC-type zinc-finger (ZF) motif, a leucine-zipper-like (LZL) region, and the internal-conserved-glycine (ICG) region between ZF and LZL (Figure 2a). The AS2/LOB domain is highly conserved in the AS2/LOB family, which consists of 42 members including AS2 in Arabidopsis [12,38,39]. Since the amino acid sequences outside of the domains are diverged among members and the transcription patterns of these genes differ for each gene, the roles of these genes in Arabidopsis development seem to be distinct. Members that might retain functions similar to those of the AS2 gene do not appear to exist in this family, because the substitution of the AS2/LOB domain of AS2 with those of other members disrupts its function [39]. Considering similarities among the AS2/LOB domains, it is, however, undeniable that these family members may retain partially overlapping functions at the molecular level. They have often been described as transcription factors [40-47]. Recent results on AS2, however, suggest that the term "transcription factor" is not appropriate for a member of this family; they are better described as novel functional factors that could play a role in gene expression.

Transcriptome analyses of as 2 and as1 mutants reveal that accumulations of ETT/ARF3, KAN2, and YAB5 transcripts, all of which are related to the abaxial cell fate, are increased in as 2 and as1, whereas those of the adaxial domain-determining HD-ZIPIII are not changed [37,48]. A subsequent systematic analysis has revealed that ETT/ARF3 is a direct target of the AS2-AS1 complex [49,50]. AS2-AS1 directly represses ETT/ARF3 by binding to the upstream region of ETT/ARF3. Furthermore, AS2-AS1 indirectly represses ETT/ARF3 via the tasiR-ARF pathway. AS2-AS1 induce the accumulation of miR390 involved in the generation of tasiR-ARF. Subsequently, both the ETT/ARF3 and ARF4 transcripts are degraded (Figure 2b). Therefore, the AS2-AS1 complex represses the expression of ETT/ARF3 in the dual pathway [49]. Several phenotypes in as2, including defects of development along the adaxial-abaxial axis, are suppressed by the ett arf4 double mutations. Consistent with these results, an overexpression of a tasiR-ARF-insensitive ETT/ARF3 CDNA produces as2-like leaves [51]. Similarly, lamina phenotypes of as 1 are also suppressed by the ett arf 4 double mutation. These results suggest that the elevated ETT/ARF3 and ARF4 expression in as 2 and as1 cause several leaf phenotypes, including defects of adaxial-abaxial polarity in these mutants. The importance of the repression of these ARFs by AS2-AS1 is further confirmed by the analysis of modifier mutations of as2 and as1, 
which are described in the next section. Increased expression levels of KAN2 and YAB5 in as2 and as1 are caused by indirect regulation by AS2-AS1 [49].

\section{(a)}

ASYMMETRIC LEAVES2 (AS2)

G

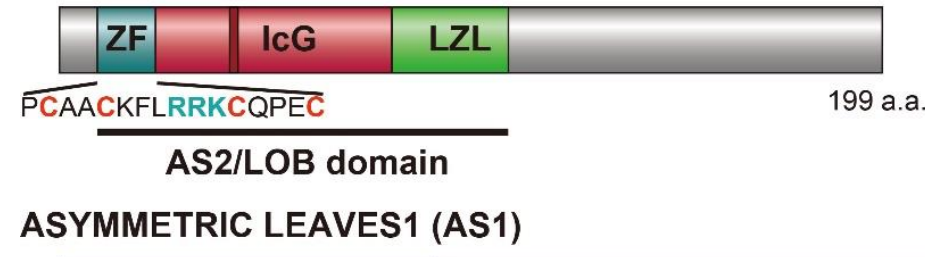

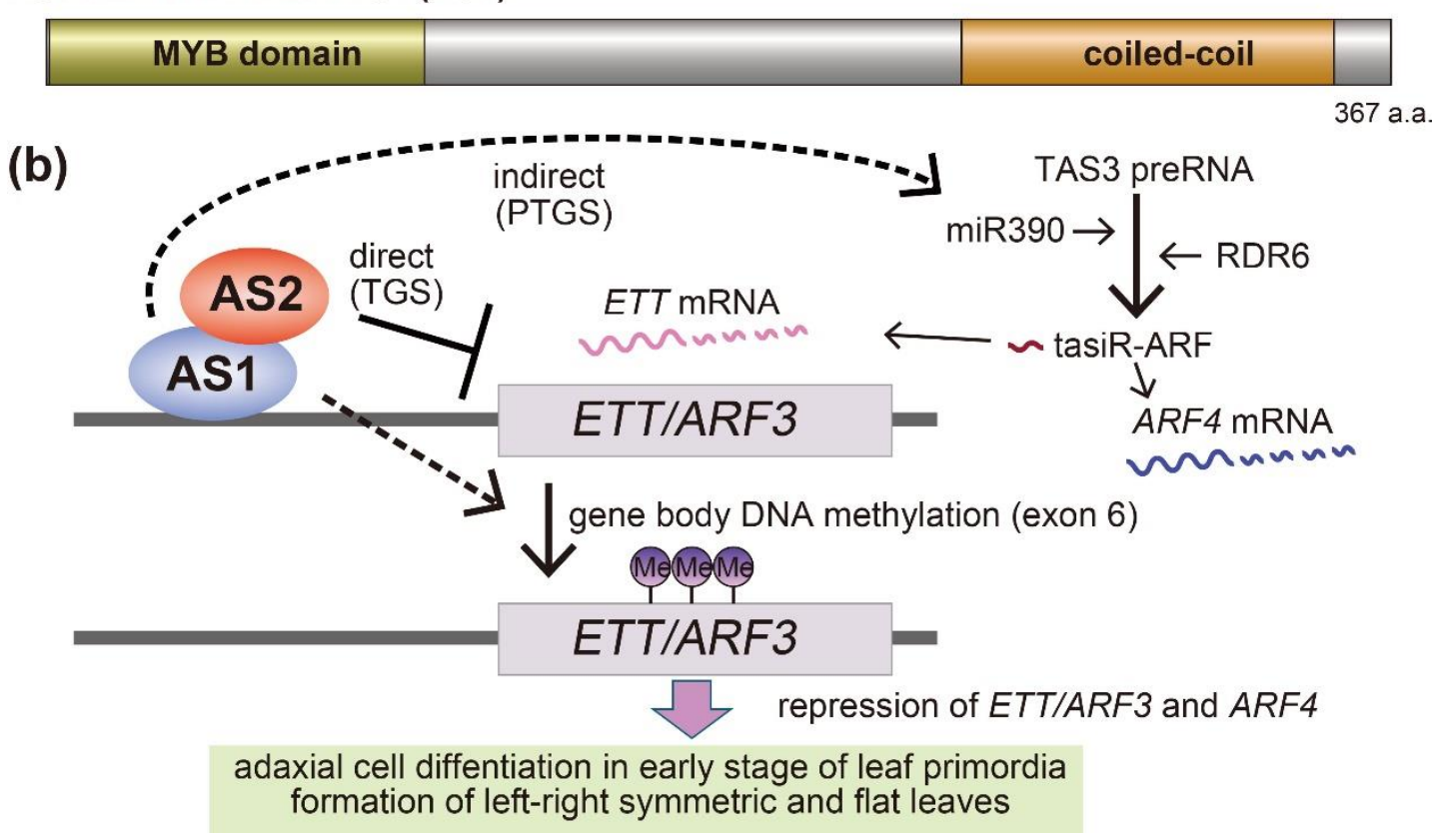

Figure 2. (a) Motif and domain organization of AS2 and AS1 proteins. The ZF motif, IcG, and LZL regions of AS2 and the MYB domain and coiled-coil structure of AS1 are shown. (b) Dual regulation of ETT/ARF3 gene expression, including that by the possibly epigenetic system of AS2-AS1. The AS2-AS1 complex represses ETT/ARF3 directly by binding to its promoter and represses ETT/ARF3 and ARF4 indirectly via stimulation of the miR390 and tasiR-ARF pathway. In addition, AS1 and AS2 maintain gene body DNA methylation of the ETT/ARF3 gene. Solid lines indicate direct regulation and dashed black lines indicate indirect regulation. Schemes of (b) are modified from ref. [2].

\section{Modifier Mutations That Enhance Defects of AS2 and AS1 in Leaf Adaxial-Abaxial Polarity}

Various mutations (about 60) that markedly enhance the defects of adaxial leaf development in as2 or as1 have been reported [2]. The genes responsible for these mutations are considered as "modifiers" or modifier genes, which affect the phenotypic expression of other genes. Double mutants generate abaxialized filamentous (needle-like, pin-shaped, pointed) leaves that have lost the adaxial domain (Figure 3). Causative mutations occur in genes that are involved in chromatin modification, biogenesis of small RNAs, and DNA replication [2,52]. Mutations in genes encoding ribosomal proteins are also identified as modifiers in as2 or as1 [2,53-58]. In addition, mutations in genes encoding nucleolar proteins, such as RNA HELICASE10 (RH10), NUCLEOLIN1 (NUC1), ROOT INITIATION DEFECTIVE2 (RID2), and APUM23 are involved in ribosome biosynthesis, and enhance the phenotypes of as2 and as1 [59-63]. Mutations in HDT1 and HDT2 for nucleolar histone deacetylases (HDACs), which localize to the nucleolus, also act as modifiers of the as 2 and as 1 phenotypes [35]. We especially focus on the roles of nucleolar proteins in this review (Table 1). 


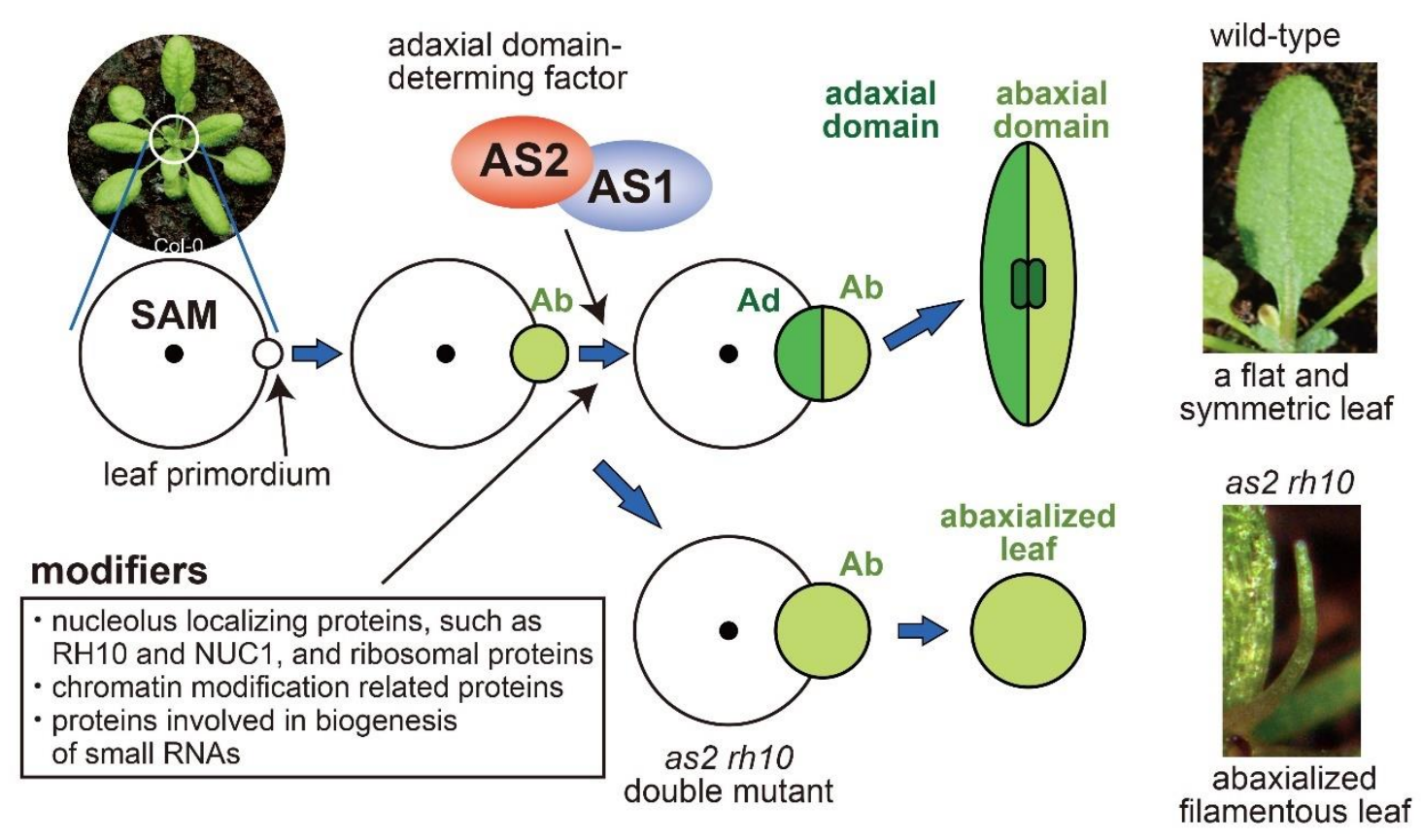

Figure 3. Development of leaves along with three axes. Top views of SAM are schematically shown by open circle. Dot indicates the center of the SAM. Adaxial and abaxial domains are shown by green and light green, respectively. AS2-AS1 contributes to the determination of adaxial domain followed by the medial-lateral growth of leaves with vasculature (indicated by dark green rectangles). Modifiers act cooperatively with AS2-AS1 at leaf primordia to develop the adaxial (Ad) domain from abaxialized $\mathrm{Ab})$ leaf primordia and to generate leaves with a flat and symmetric structure. The double mutation into AS2 (or AS1) and modifiers results in the production of abaxialized filamentous leaves. Photograph of wild-type leaf is modified from ref. [64].

Transcript levels of several abaxial-determining genes (KAN2, YAB5, ETT/ARF3, and ARF4) are slightly upregulated in the as2-1 single mutant and each of the modifier single mutants and are markedly increased in the as 2-1 and modifier double mutants (for example, as 2-1 rh10-1). When the double mutations of ETT/ARF3 and ARF4 are introduced to double mutants with as2-1 and one of the modifier mutations, such as as 2-1 nuc1-1 or as 2-1 rh10-1, the abaxialized filamentous leaves phenotype (e.g., as 2 rh10 leaves in Figure 3) is restored to the expanded shapes [59,64,65]. These results show that the upregulation of these $A R F$ genes in the double mutants is responsible for the disappearance of their adaxial specification in their filamentous leaves. These genetic observations suggest that the repression of these ARF genes by the synergistic action of AS2-AS1 and modifier proteins is critical for the proper development of the adaxial domain. These results suggest that modifier proteins act cooperatively with AS2-AS1 to generate flat and symmetric leaves (Figure 3). The modifier genes that encode nucleolar proteins are summarized below.

Nucleoli are membrane-less organelles that appear to assemble through the phase separation of their molecular components [66]. The nucleoli contain internal subcompartments of ribosome biogenesis such as rDNA transcription, the processing of the precursor rRNA to generate mature rRNAs, assembly of these rRNAs, and many ribosomal proteins to generate each of small and large subunits of ribosomes. Genomic regions positioned in close proximity to the nucleolus are known as nucleolus-associated domains (NADs). Recent analyses of DNA sequencing that have been purified along with the nucleolus suggests that NADs in both animal and plant cells are enriched in regions displaying heterochromatic signatures $[67,68]$.

NUCLEOLIN1 (NUC1) gene: Nucleolin, one of the most abundant non-ribosomal proteins in the nucleolus, has been described in a large variety of organisms [69]. The Arabidopsis genome encodes two 
nucleolin-like proteins-NUC1 and NUC2. Only the NUC1 gene, however, is ubiquitously expressed under normal growth conditions [61].

The single mutant $n u c 1-1$ exhibits a pointed narrow leaf shape, which is often observed in other modifier mutations $[59,61,70,71]$. In nuc1-1 plants, nucleolar disorganization is observed and accumulated levels of pre-rRNA precursors are detected, indicating that NUC1 is involved in the processing of pre-rRNAs [61,72-74]. An analysis of high-throughput sequencing of DNA purified from the nucleoli of the NUC1 mutant revealed that NUC1 is required for global genomic organization and stability $[67,75]$. In addition, human nucleolin is reported to be an assembly intermediate of the SSUP and its candidate components [62,76,77]. The as2-1 nuc1-1 and as1-1 nuc1-1 double mutant plants generate filamentous leaves. These mutant phenotypes are partially suppressed by the mutation in $E T T / A R F 3$, indicating a role in the repression of ETT/ARF3 gene expression for the formation of flat symmetric leaves in the wild-type plants [65].

RNA HELICASE10 (RH10) gene: The mutation of $r h 10$ was isolated as a modifier of as 2 and as1. Transcript levels of the abaxial genes, such as ETT/ARF3 and ARF4, are elevated in as2-1 rh10-1, generating abaxialized filamentous leaves. This phenotype is suppressed by the ett/arf3 arf4 double mutation, indicating a role in the repression of ETT/ARF3 and ARF4 gene expression for the formation of flat symmetric leaves in the wild-type plants [59]. RH10 is localized to the nucleolus in leaf primordia cells and is an ortholog of budding yeast Rrp3 and human DDX47, which belong to the DEAD-box RNA helicase family, a component of the nucleolar protein complex designated as the small subunit (SSUP) involved in 18S rRNA biogenesis [77,78]. It is reported that the DEAD-box RNA helicase family has an indispensable role in gene regulation through RNA metabolism [77-80]. DDX47 is necessary for maintaining the pluripotency of mouse stem cells [81]. In rh10-1, various defects are detected in SSUP-related events, such as the accumulation of 35S/33S rRNA precursors and a reduction in the 18S/25S ratio [59]. Nucleoli are enlarged in the rh10-1 mutant [59]. RH10 may be involved in the early stages of processing reactions of the precursors of ribosomal RNAs.

ROOT INITIATION DEFECTIVE2 (RID2) gene: RID2 encodes an evolutionarily conserved methyltransferase-like protein, an orthologous protein of the budding yeast, Bud23, which exhibits tight functional and physical interactions with some of the SSUP components [82-84]. The RID2 protein is localized in nuclei and accumulates mainly within nucleoli [60]. RID2 is involved in the processing of pre-rRNAs at various early stages [85,86]. Nucleolar enlargement is also observed in the rid 2 mutant. A mutation in the RID2 gene has an effect on the adaxial-abaxial organization of leaves on the as 2 background, generating filamentous leaves and upregulating ARF3/ETT and ARF4 as found in other modifier mutants and as2-1 [59].

APUM23 gene: APUM23, which encodes a protein that is a member of the Pumilio/PUF domain protein family with its pumilio-like RNA-binding repeats, is localized to the nucleolus and is involved in the processing of 35S pre-rRNA [63,87]. The apum23-1 mutant has enlarged nucleoli [63]. The double mutants apum23-3 as2-2 and apum23-3 as1-1 produce filamentous leaves, suggestive of the involvement of APUM23 in leaf development, similarly as with other nucleolar modifiers.

Ribosomal protein genes: It is worth noting that Arabidopsis double mutants of the ribosomal protein gene $r p s 6 a-1$, which has a 9 bp deletion in the coding region of RPS6A, and as2-1 exhibit strong adaxial leaf defects, as indicated by the fact that $80 \%$ of the double mutant leaves are filamentous [56]. Rps6 of budding yeast is one of five small-ribosomal-subunit proteins (Rps4, Rps6, Rps7, Rps9, and Rps14) that are components of the SSUP, which is a large ribonucleoprotein required for the biogenesis of the $18 S$ rRNA [88]. Genetic interactions between AS2/AS1 and homologues of Rps4, Rps7, Rps9, and Rps14 in Arabidopsis have yet to be examined. Three other RPS mutants ( $r p s 23 B, r p s 23 B$, and rps23B) and fourteen $R P L$ genes for ribosomal proteins in the large subunit also enhance the leaf phenotype in as 2 and/or as1 (Table 1). It would also be intriguing to examine the relationships between the adaxial defects and ribosomal protein genes for such ribonucleoprotein complexes as a large subunit processome [89] in the nucleolus of Arabidopsis [53-57]. Therefore, the wild-type AS2 
gene, which is specific in plants, may appear to attenuate defects resulting from mutations in the ribosomal protein gene.

HDT1 and HDT2 genes: HDT1, which encodes plant-specific nucleolar histone deacetylases (HDACs), is one of the factors responsible for gene silencing of megabase-scale rRNA loci and gene dosage control in nucleolar dominance $[90,91]$, which are achieved by a highly condensed heterochromatic state that is associated with $\mathrm{H} 3 \mathrm{~K} 9 \mathrm{me} 2$ and 5-methylcytosine enrichment in the promoter regions of rDNA genes [91]. Knockdown of the Arabidopsis genes HDT1 and HDT2 for nucleolar histone deacetylases (HDACs) enhances the leaf adaxial defects of as 2 and as 1 to generate severely abaxialized filamentous leaves, as seen in as 2-1 rh10-1 [35]. Considering the role of HDT1 in an epigenetic silencing of rDNAs (in nucleolar dominance), such as in the allopolyploid hybrid Arabidopsis suecica between A. thaliana and A. arenosa [91], the cooperative repression of the abaxial genes by AS2 and epigenetic silencing system of rDNAs described above are involved in the development of flat symmetric leaves.

Table 1. Gene mutations that act as modifiers to enhance leaf adaxial-abaxial abnormalities in as2 and as1.

\begin{tabular}{|c|c|c|c|c|}
\hline 1. Gene Name (Mutant Name) & 2. AGI Code & 3. Protein & $\begin{array}{l}\text { 4. Cellular Process and } \\
\text { Status }\end{array}$ & 5.References \\
\hline \multicolumn{5}{|l|}{ I. Genes involved in rRNA processing } \\
\hline NUCLEOLIN1 (nuc1) & AT1G48920 & NUCLEOLIN & $\begin{array}{l}\text { rRNA processing and } \\
\text { ribosome biogenesis } \\
\text { Components of } \\
\text { SSUP-like complex }\end{array}$ & {$[59,61,70,71]$} \\
\hline RNA HELICASE10 (rh10) & AT5G60990 & $\begin{array}{l}\text { DEAD-box RNA helicase } \\
\text { family protein }\end{array}$ & $\begin{array}{l}\text { pre-rRNA processing } \\
\text { Components of } \\
\text { SSUP-like complex }\end{array}$ & [59] \\
\hline $\begin{array}{c}\text { ROOT INITIATION DEFECTIVE2 } \\
(\text { rid2) }\end{array}$ & AT5G57280 & $\begin{array}{c}\text { RNA } \\
\text { methyltransferase-like } \\
\text { protein }\end{array}$ & pre-rRNA processing & {$[59,60]$} \\
\hline APUM23 (арит23) & AT1G72320 & $\begin{array}{l}\text { Pumillio protein } \\
\text { containing PUF domain }\end{array}$ & $\begin{array}{l}\text { pre-rRNA processing and } \\
\text { rRNA maturation }\end{array}$ & [63] \\
\hline \multicolumn{5}{|l|}{ II. Genes for ribosomal proteins } \\
\hline$R P L 4 D(r p l 4 d)$ & AT5G02870 & \multirow{18}{*}{ Ribosomal proteins } & \multirow{18}{*}{$\begin{array}{l}\text { Subunits of ribosome; } \\
\text { components of } \\
\text { pre-rRNA-protein complex }\end{array}$} & \multirow{18}{*}[53-57]{} \\
\hline RPL5A (pgy3/ae6/oli5/rpl5a) & AT3G25520 & & & \\
\hline RPL5B (rpl5b/oli7) & AT5G39740 & & & \\
\hline$R P L 7 B(r p l 7 b)$ & AT2G01250 & & & \\
\hline RPL9c (rpl9c/pgy2) & AT1G33140 & & & \\
\hline RPL10aB (rpl10ab/pgy1) & AT2G27530 & & & \\
\hline RPL18C (rpl18c) & AT5G27850 & & & \\
\hline RPL24b (stv1) & AT3G53020 & & & \\
\hline RPL27ac (rpl27ac) & AT1G70600 & & & \\
\hline RPL28A (ae5/rpl28a) & AT2G19730 & & & \\
\hline PRL36aB (api2) & AT4G14320 & & & \\
\hline RPL36aA (rpl36aa) & AT3G59540 & & & \\
\hline RPL38B (rpl38b) & AT4G31985 & & & \\
\hline RPL39C (rpl39c) & AT3G23390 & & & \\
\hline$R P S 6 A *(r p s 6 a)$ & AT4G31700 & & & \\
\hline$R P S 21 B(r p s 21 b)$ & AT3G53890 & & & \\
\hline RPS24B (rps24b) & AT5G28060 & & & \\
\hline RPS28B (rps28b) & AT5G03850 & & & \\
\hline \multicolumn{5}{|l|}{$\begin{array}{l}\text { III. Genes involved in histone } \\
\text { modification }\end{array}$} \\
\hline HDT1 (hdt1/hd2a/hda3) & AT3G44750 & $\begin{array}{l}\text { Histone deacetylase } \\
\text { (plant-specific class) }\end{array}$ & $\begin{array}{c}\text { Deacetylation of } \\
\text { nucleosomal histone } \mathrm{H} 3 \text {, } \\
\text { transcription of rDNAs }\end{array}$ & {$[35,90,92]$} \\
\hline HDT2 (hdt2/hd2b) & AT5G22650 & $\begin{array}{l}\text { Histone deacetylase } \\
\text { (plant-specific class) }\end{array}$ & $\begin{array}{c}\text { Deacetylation of } \\
\text { nucleosomal histone } \mathrm{H} 3 \text {, } \\
\text { transcription of rDNAs }\end{array}$ & {$[35,90,92]$} \\
\hline
\end{tabular}

* Rps6 of budding yeast is one of the proteins that was identified as a bona fide component of the SSUP. 


\section{AS2 Bodies: Perinucleolar Granules Co-Localized Partially with the Chromocenter}

The AS2-fused YFP (Yellow Fluorescent Protein) was used to investigate subnuclear localization of AS2 protein. The AS2 protein is localized to perinucleolar bodies known as AS2 bodies as well as to the nucleoplasm in the leaf cells of Arabidopsis and some interphase cells of a cultured tobacco cell line BY-2 (Figure 4) [35,93]. As mentioned in Section 2, AS2 has the AS2/LOB domain that includes ZF, IcG, and LZL regions (Figure 2a), which are essential for the formation of AS2 bodies at the perinucleolar regions [94]; the carboxyl-terminal half of AS2 is nonessential for the body formation, but essential for the developmental function of AS2 [12,93]; AS1 co-localizes with AS2 in the cell bodies (Figure 4) [35].

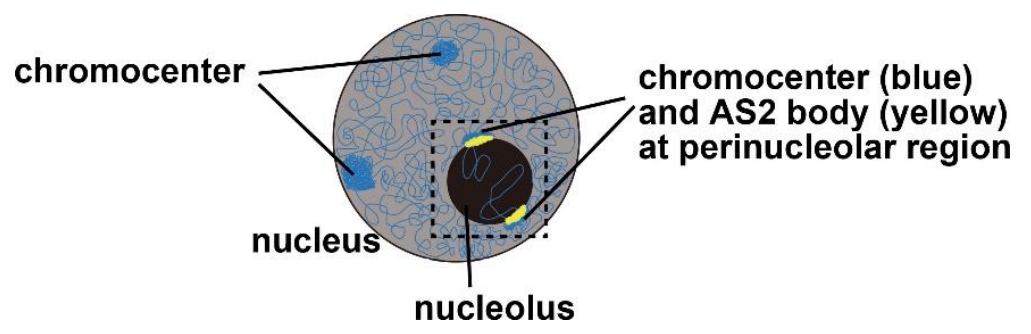

Figure 4. Schematic representation of the nucleus is shown. Chromosomes and AS2 bodies are indicated by blue and yellow, respectively. AS1 and AS2 are co-localized on AS2 bodies.

In addition, the amino acid residues that are highly conserved within and adjacent to the ZF motifs of all the AS2 family members are critically important for the body formation: four cysteine residues; proline and alanine residues next to the first cysteine residue; the RRK cluster (Figure 2). The RRK sequence is found within proposed nucleolar localization signals (NoLSs) [95-98] and it is likely that this cluster participates in the perinucleolar localization of AS2. These amino acid residues and three regions (ZF, ICG, and LZL) in the AS2/LOB domain are also required for the ability of AS2 to complement the as 2 mutation and to bind to the coding sequence of the target ARF3/ETT gene, showing that the formation of AS2 bodies is related to the genetic functions of AS2 in leaf formation. The AS2 bodies appear to be located to the peripheral regions of nucleoli and are partially overlapped with perinucleolar chromocenters with condensed chromatin-containing ribosomal RNA genes (45S rDNA repeats), suggesting that AS2 bodies interact with 45S rDNA repeats (Figure 4) [94].

It should be noted that the proportions of cells in which AS2 bodies are generated in plants differ from those in cultured cells. AS2 bodies are detected in only a few percentages of interphase cells of the tobacco-cultured cell line BY-2 and the Arabidopsis-cultured cell line MM2d transformed with the AS2-fused YFP constructs [93,94]. AS2 bodies are, however, detected in almost all interphase cells of the adaxial domain in leaf primordia of the Arabidopsis plants with the AS2-fused YFP construct [94]. The average number of AS2 bodies per YFP-positive cells at interphase (and/or the G0 stage) in leaf primordia was calculated as 1.9 [94]. In contrast, AS2 bodies are formed in all M phase cells of both cell lines, MM2d and BY-2 and in all M phase cells of leaf primordia; AS2 bodies are separated into daughter cells during the M phase progression [93,94]. These observations imply that the formation and distribution of AS2 bodies might be modulated developmentally in plants and in a cell-cycle-dependent manner.

The subcellular localization of AS2 appears to be subject to multiple controls, since AS2 was exported to the cytoplasm via the action of the geminivirus-encoded nuclear shuttle protein $[12,94,99]$.

Although mechanisms for the formation of AS2 bodies and their roles in repressing the target genes for leaf development have yet to be discovered, the identification of AS2 body components and investigations of how these molecules interact within the nucleolus would provide answers for these questions. 


\section{AS2-AS1 Binds to Exon 1 of the Target Gene ETT/ARF3, and Is Involved in Maintaining CpG Methylation in Exon 6}

Four mechanisms have been investigated for the repression of target gene ETT/ARF3 expression by AS2-AS1: (1) direct binding of the AS1-AS2 complex to the 5'-upstream regions of ETT/ARF3 to reduce the expression activity of ETT/ARF3 (Figure 5) [49]; (2) indirect activation of miR390-dependent post-transcriptional gene silencing to negatively regulate both ETT/ARF3 and ARF4 (Figure 2b) $[49,50]$; (3) direct binding of AS2 to the synthetic GCGGCG-containing nucleotides [47,50], and exon 1 of the ETT/ARF3 gene containing the CGCCGC (Figure 5) [65]; (4) maintenance of the status of gene body (CPG) methylation in exon 6 of ETT/ARF3 (Figure 5) $[49,65,100]$. In the present review, we focus on the last two topics.

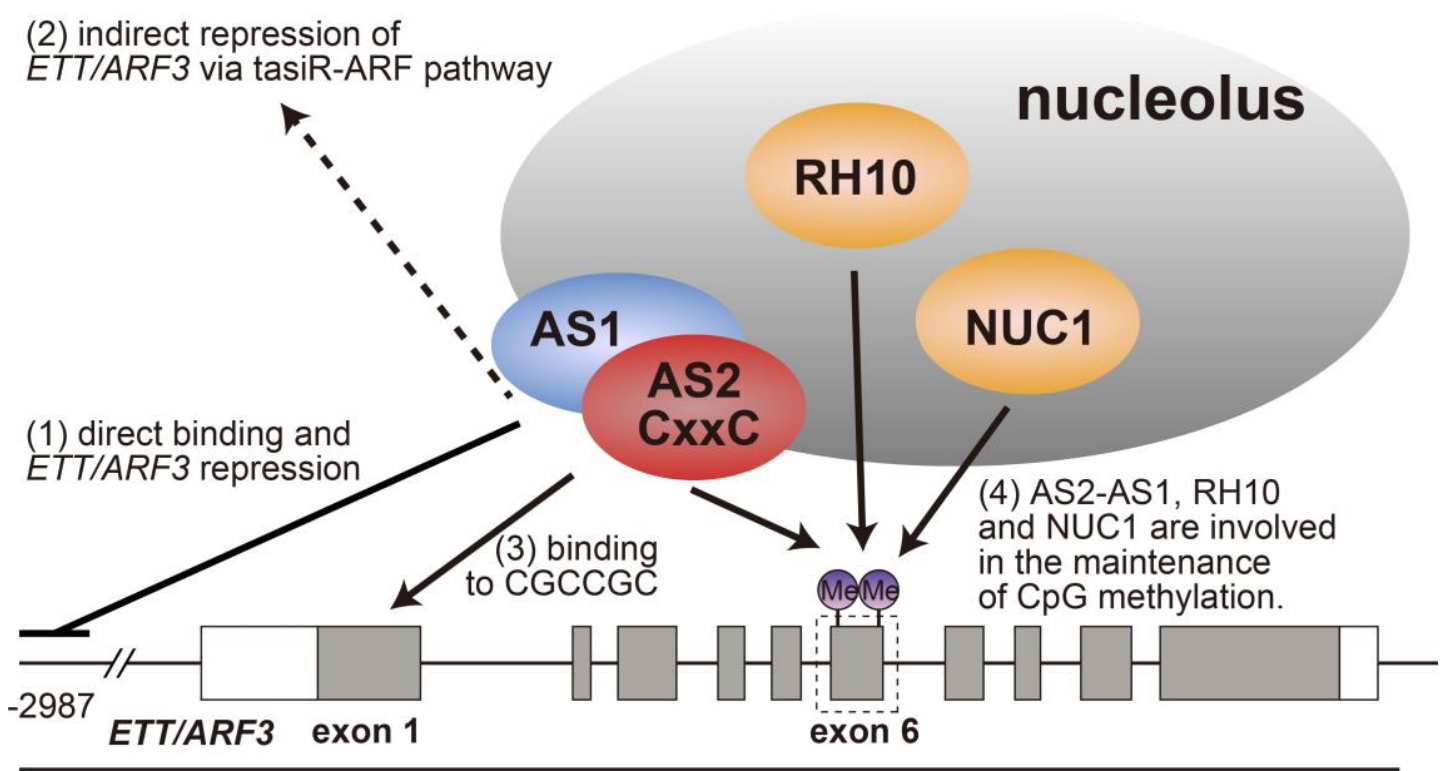

\section{leaf adaxialization}

Figure 5. Molecular relationships between AS2-AS1 and the target gene ETT/ARF3. AS1-AS2 directly binds the ETT/ARF3 regulatory region and represses ETT/ARF3 expression. AS2 binds to the specific CGC repeat sequence in exon 1. AS2-AS1, RH10, and NUC1 are involved in the maintenance of CpG methylation in exon 6 . RH10 and NUC1 are proteins localized in the nucleolus.

Several protein members of the AS2/LOB family, including AS2, bind synthetic double-stranded DNAs containing the GCGGCG sequence [101]. AS2, specifically, also binds in vitro the double-stranded CGCCGC sequence in exon 1 of the target gene ETT/ARF3 [65]. The zinc-finger motif containing the RRK (Arg-Arg-Lys) sequence in AS2 is essential for this binding [65], the formation of AS2 bodies and functions in the development of leaves with normal shapes [94]. Modes of molecular interactions between the amino acid residues in RRK and each of the deoxyribonucleotides in GCGGCG have recently been proposed based on the results of SEC-SAXS (size exclusion chromatography-small angle X-ray scattering) experiments [47]. Since 32 out of 42 members of the family harbor the RRK and/or RRR sequence in the ZF motifs [12], it should be informative to investigate the possible roles of the clusters of these basic amino acid residues in other members in plant physiology, development, and growth [102].

AS2 and AS1 play a role in maintaining cytosine methylation mediated by METHYLTRANSFERASE1 (MET1) in six CpG dinucleotides in exon 6 of ETT/ARF3 (Figure 5) [49]. Because levels of CpG methylation are inversely related to the ETT/ARF3 transcript levels, AS2 and AS1 possibly regulate the transcriptional repression of ETT/ARF3 through CpG methylation in the recruitment of methylation 
activity and/or inhibition of demethylation activity at exon 6 [103]. As described in Section 3, mutations in the RH10, NUC1, and RID2 genes for nucleolar proteins enhance defects in leaf morphology in the as 2 mutant and, in parallel with this observation, result in an increase in the transcript level of target genes ETT/ARF3 and ARF4. The levels of CpG methylation at some of the CpG dinucleotides in exon 6 of ETT/ARF3 decrease in rh10 and nuc1 mutants, and further decrease in rh10 as 2 and nuc1 as2, suggesting that these nucleolar proteins, in addition to AS2, also take part in maintaining the cytosine methylation of CpG dinucleotides in exon 6 of ETT/ARF3 [65,103].

How can AS2 be involved in maintaining MET1-regulated CpG methylation in exon 6 of the ETT/ARF3 gene? MET1 is an ortholog of the Dnmt1 of vertebrates and acts as DNA methyltransferase, which methylates hemimethylated $\mathrm{CpG}$, converting it to fully methylated CpG during DNA replication [104,105]. MET1 is part of a putative protein complex involved in the maintenance of DNA methylation in Arabidopsis [106-111]. MET1 is similar to Dnmt1, in terms of the domain organization [109,112], except that MET1 has no amino acid sequence for the ZF-CxxC motif. If AS2 forms a protein complex with MET1, AS2 provides the ZF motif, which has DNA binding activity, as described above in this section, to the MET1-containing putative protein complex. The promoter regions of inactive $45 \mathrm{~S}$ rDNAs in Arabidopsis are highly methylated by MET1 and their chromatin states are highly condensed at perinucleolar regions [113,114]. MET1 requires NUC1, one of the AS2 modifiers, and nucleolar histone deacetylase HDA6 for this methylation $[113,114]$ and directly interacts with HDA6 [115,116], which is also associated with AS2 and AS1 [36]. The CpG methylation system for the $45 \mathrm{~S}$ rDNA might be also involved in CpG methylation in the ETT/ARF3 gene around perinucleolar areas; the ETT/ARF3 gene might be recruited to such an area by an action of AS2 (Figure 6).

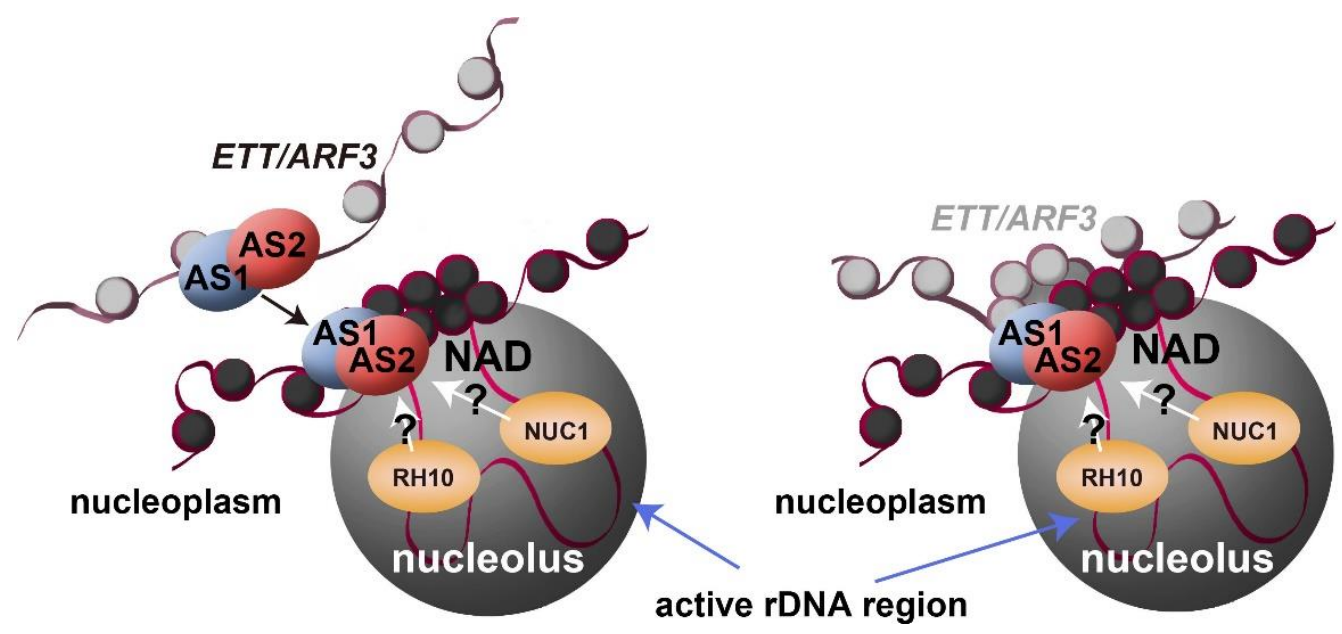

Figure 6. Models of the roles of nucleolar proteins in AS2-AS1 involved in epigenetic regulation of the ETT/ARF3 gene. Nucleolus and surrounding structures are shown. Nucleosomes are indicated by coiled structure composed of red lines (DNA) and light/dark grey circle (histone octamer). Different genomes are distinguished by different darkness of nucleosomes. NUC1 affected the localization patterns of AS2 bodies at the peripheral region of the nucleolus, which are required for leaf development. AS2 bodies are partially overlapped with chromocenters, represented by dense nucleosome at the peripheral region of the nucleolus. The $45 \mathrm{~S}$ rDNA repeat loci include transcriptionally active and inactive regions, which chromosomal status are loosened in the nucleolus and condensed on the peri-nucleolus (overlapping with chromocenter), respectively, suggestive of an interaction of AS2 bodies with inactive 45S rDNA. RH10 and NUC1 in addition to AS2 are involved in the maintenance of CpG methylation in exon 6 of ETT/ARF3 in the nucleoplasm (left panel) or in AS2 bodies (right panel). NUC1 is involved in the maintenance of CPG methylation in 45S rDNA.

The AS2-AS1 complex is also involved in the establishment of leaf proximal-distal polarity to repress the class 1 KNOX homeobox genes BREVIPEDICELLUS (BP), KNAT2, and KNAT6 (Figure 1) [18]. The AS2-AS1 complex physically interacts with CURLY LEAF (CLF), the polycomb repressive complex 2 
(PRC2) core component, and LIKE-HETEROCHROMATIN PROTEIN1 (LHP1), the PRC1 component, and recruits PRC2 to the homeobox genes BP and KNAT2 [117,118]. AS2-AS1 interacts with the BP promoter, likely through the recruitment of the chromatin-remodeling factor HIRA (histone-regulator A) and forms a repressive chromatin state [19]. AS2-AS1 also interacts with LEAF FLOWER RELATED (LFR) in the chromatin remodeling complex and is associated with H3K27me3 in the BP gene, but not with the ETT/ARF3 gene [119]. AS2-AS1 is required for the correct temporal repression of ETT/ARF3, which involves a PRC2-independent mechanism [50]. Despite their pivotal role, the means by which AS2-AS1 epigenetically represses ETT/ARF3 in the establishment of leaf adaxial-abaxial polarity remains unsolved.

\section{Subcellular localization of AS2}

Although it is often reported that AS2 and other members of the AS2/LOB family are nuclear proteins $[2,12,35,38,93,120]$, mechanisms of the nuclear localization of AS2 protein are poorly understood. The RRK sequence in the zinc-finger motif of AS2 (Figure 2a) is only a basic amino acid cluster, which is thought to be critical for nuclear localization. The examination of subcellular localization of the mutant as2 (as2-RRK/3A) with the alanine replacement at the RRK sequence in the zinc-finger motif (Figure 2a) with the alanine cluster, however, shows that the mutant protein is still present in the nucleoplasm; it is not exported to the cytoplasm and does not form the AS2 bodies at the perinucleolar region [94]. These observations show that the RRK sequence is not involved in the nuclear localization of AS2. This result is consistent with the previous finding [121]: that is, the mutant proteins of ASL18/LBD16, another member of the AS2/LOB family, from which the RRK sequence is deleted are still localized to the nucleus and nuclear localization signals are proposed to be present in the coiled-coil sequence and the carboxyl-terminal region. Furthermore, the mutant as 2 protein that lacks the IcG region is exclusively localized to the cytoplasm [94]. It is also reported that AS2 was exported to the cytoplasm via the action of the geminivirus-encoded nuclear shuttle protein and localized to the plant P-body complex [99]. Therefore, the AS2 protein might be subject to multiple subcellular localization controls, depending on its interactions with other proteins and other unknown cellular conditions.

As described above, 32 among the 42 members of the AS2/LOB family harbor ZF motifs, the amino acid sequences of which include RRK or RRR sequences [12,38]. The observation that the as 2 mutant lacking RRK is localized to the nucleoplasm, but does not form AS2 bodies at the nucleolar periphery, suggests that RRK appears to be involved in the transport of AS2 to the perinucleolar region and/or to the formation of AS2 bodies. The RRK sequence is present within the proposed NoLSs [95-98]. It is intriguing to test whether this cluster of the basic amino acid residues in the zinc-finger could be directly involved in the transfer to the peripheral region of the nucleoli from the nucleoplasm and/or the formation of AS2 bodies by a phase separation mechanism, because the nucleolus and many nucleolar bodies are proposed to be formed through such a physico-chemical molecular interaction [122].

\section{Possible Roles of AS2 Bodies in Epigenetic Repression of ETT/ARF3}

As described in Section 3, the level of the leaf abaxial gene ETT/ARF3 expression is influenced by modifier proteins that are localized to the nucleolus. For example, the AS2-AS1 complex binds directly to the upstream region of the ETT/ARF3 gene to repress its transcription [49,64]. Furthermore, the ETT/ARF3 transcriptional level is altered by mutations in various genes for nucleolus-localized proteins, such as RH10, RID2, and NUC1, which affect the biogenesis of ribosomal RNAs and the formation of the nucleolus with a properly organized morphology [59-61]. Perturbation of rRNA biogenesis correlates with structural disorders of the nucleolus, such as nucleolar enlargement in plant cellsand in animal cells $[60,85,86,123]$. It is, however, still unknown how structural disorders of the nucleolus affects leaf development mediated by AS2-AS1.

Perinucleolar regions might provide the molecular architectures, such as nucleolus-associated chromatin domains (NADs), which correspond to regions of low transcriptional levels $[67,68,124,125]$. In Arabidopsis, many of $45 \mathrm{~S}$ rRNA genes are condensed as heterochromatin and silenced by 
epigenetic mechanisms that include DNA methylation and histone modification at the periphery of the nucleolus [114,126-128]. MET1, HDA6, and chromatin assembly factor (CAF-1) are all involved in the formation of such an epigenetic state in the perinucleolar subdomain [114,126,127]. AS2 and AS1, which are associated with HDA6 [36], are colocalized to AS2 bodies in the peripheral region of the nucleolus (Figures 4 and 6) $[35,93,94]$. The ETT/ARF3 gene undergoes MET1-dependent CpG methylation in exon 6 [49]. As described in Sections 4 and 6, mutant proteins of AS2 (as2-RRK/3A, Figure 2a) that do not form AS2 bodies are not functional in leaf morphogenesis [94]. Mutations in RH10, RID2, and NUC1 might affect the integrity of nucleolar morphology [59-61], which would then alter the transcriptional patterns of ETT/ARF3, a target gene of AS2, although the subnucleolar localization of the target gene to the peripheral subdomain (Figure 6) has yet to be demonstrated. It is an interesting problem to elucidate how the ETT/ARF3 gene transcribed by RNA polymerase II is regulated in the nucleolus or its peripheral region.

Recently, AS2 was shown to bind to DNAs other than ETT/ARF3 [129]. Since AS2 is a plant-specific DNA binding protein, elucidation of the interaction between AS2 and these DNA molecules should uncover a more global and novel regulatory system mediated by AS2 and the nucleolus in plant cells $[19,101]$.

Author Contributions: H.I. prepared the manuscript related to Sections 1, 2, 4 and 6. H.T. prepared the manuscript related to Section 5. Y.M. prepared the manuscript related to Sections 4 and 6. C.M. supervised all the research in this manuscript and prepared the manuscript related to Sections 1-3,5 and 7. All authors have read and agreed to the published version of the manuscript.

Funding: This work was supported by the Japan Society for the Promotion of Science (JSPS) KAKENHI (grant numbers JP18H03330, JP18K06297, JP19K22892, JP20K06702 and 16H06279 (PAGS)) and the Research Foundation for the Electrotechnology of Chubu.

Acknowledgments: The authors are grateful to Takanori Suzuki at Ishihara Sangyo Kaisha LTD, Yuki Sakamoto at Osaka University, Sachihiro Matsunaga and Tetsuya Higashiyama at University of Tokyo, Daisuke Kurihara and Shogo Matsumoto at Nagoya University, Michiko Sasabe at Hirosaki University, and Shoko Kojima and Sayuri Ando at Chubu University for their helpful discussions.

Conflicts of Interest: The authors declare no conflict of interest.

\author{
Abbreviations \\ FISH Fluorescence in situ Hybridization \\ GFP Green Fluorescent Protein \\ BY-2 Bright Yellow-2 \\ tasiR trans-acting small interfering RNA
}

\title{
References
}

1. Bar, M.; Ori, N. Compound leaf development in model plant species. Curr. Opin. Plant. Biol. 2015, 23, 61-69. [CrossRef] [PubMed]

2. Machida, C.; Nakagawa, A.; Kojima, S.; Takahashi, H.; Machida, Y. The complex of ASYMMETRIC LEAVES (AS) proteins plays a central role in antagonistic interactions of genes for leaf polarity specification in Arabidopsis. Wiley Interdiscip. Rev. Dev. Biol. 2015, 4, 655-671. [CrossRef] [PubMed]

3. Fouracre, J.P.; Poethig, R.S. The role of small RNAs in vegetative shoot development. Curr. Opin. Plant. Biol. 2016, 29, 64-72. [CrossRef] [PubMed]

4. Du, F.; Guan, C.; Jiao, Y. Molecular Mechanisms of Leaf Morphogenesis. Mol. Plant 2018, 11, 1117-1134. [CrossRef] [PubMed]

5. Alvarez, J.P.; Furumizu, C.; Efroni, I.; Eshed, Y.; Bowman, J.L. Active suppression of a leaf meristem orchestrates determinate leaf growth. eLife 2016, 5. [CrossRef] [PubMed]

6. Conklin, P.A.; Strable, J.; Li, S.; Scanlon, M.J. On the mechanisms of development in monocot and eudicot leaves. New Phytol. 2019, 221, 706-724. [CrossRef]

7. Kuhlemeier, C.; Timmermans, M.C. The Sussex signal: Insights into leaf dorsiventrality. Development 2016, 143, 3230-3237. [CrossRef] 
8. Satterlee, J.W.; Scanlon, M.J. Coordination of Leaf Development Across Developmental Axes. Plants 2019, 8, 433. [CrossRef]

9. Nakata, M.T.; Tameshige, T.; Takahara, M.; Mitsuda, N.; Okada, K. The functional balance between the WUSCHEL-RELATED HOMEOBOX1 gene and the phytohormone auxin is a key factor for cell proliferation in Arabidopsis seedlings. Plant. Biotechnol. 2018, 35, 141-154. [CrossRef]

10. Byrne, M.E.; Barley, R.; Curtis, M.; Arroyo, J.M.; Dunham, M.; Hudson, A.; Martienssen, R.A. Asymmetric leaves 1 mediates leaf patterning and stem cell function in Arabidopsis. Nature 2000, 408,967-971. [CrossRef]

11. Semiarti, E.; Ueno, Y.; Tsukaya, H.; Iwakawa, H.; Machida, C.; Machida, Y. The ASYMMETRIC LEAVES2 gene of Arabidopsis thaliana regulates formation of a symmetric lamina, establishment of venation and repression of meristem-related homeobox genes in leaves. Development 2001, 128, 1771-1783. [PubMed]

12. Iwakawa, H.; Ueno, Y.; Semiarti, E.; Onouchi, H.; Kojima, S.; Tsukaya, H.; Hasebe, M.; Soma, T.; Ikezaki, M.; Machida, C.; et al. The ASYMMETRIC LEAVES2 gene of Arabidopsis thaliana, required for formation of a symmetric flat leaf lamina, encodes a member of a novel family of proteins characterized by cysteine repeats and a leucine zipper. Plant Cell Physiol. 2002, 43, 467-478. [CrossRef] [PubMed]

13. Lin, W.C.; Shuai, B.; Springer, P.S. The Arabidopsis LATERAL ORGAN BOUNDARIES-domain gene ASYMMETRIC LEAVES2 functions in the repression of KNOX gene expression and in adaxial-abaxial patterning. Plant Cell 2003, 15, 2241-2252. [CrossRef] [PubMed]

14. Timmermans, M.C.; Hudson, A.; Becraft, P.W.; Nelson, T. ROUGH SHEATH2: A Myb protein that represses knox homeobox genes in maize lateral organ primordia. Science 1999, 284, 151-153. [CrossRef]

15. Tsiantis, M.; Schneeberger, R.; Golz, J.F.; Freeling, M.; Langdale, J.A. The maize rough sheath2 gene and leaf development programs in monocot and dicot plants. Science 1999, 284, 154-156. [CrossRef]

16. Waites, R.; Selvadurai, H.R.; Oliver, I.R.; Hudson, A. The PHANTASTICA gene encodes a MYB transcription factor involved in growth and dorsoventrality of lateral organs in Antirrhinum. Cell 1998, 93, 779-789. [CrossRef]

17. Waites, R.; Hudson, A. The Handlebars gene is required with Phantastica for dorsoventral asymmetry of organs and for stem cell activity in Antirrhinum. Development 2001, 128, 1923-1931.

18. Ikezaki, M.; Kojima, M.; Sakakibara, H.; Kojima, S.; Ueno, Y.; Machida, C.; Machida, Y. Genetic networks regulated by ASYMMETRIC LEAVES1 (AS1) and AS2 in leaf development in Arabidopsis thaliana: KNOX genes control five morphological events. Plant J. 2010, 61, 70-82. [CrossRef]

19. Guo, M.; Thomas, J.; Collins, G.; Timmermans, M.C. Direct repression of KNOX loci by the ASYMMETRIC LEAVES1 complex of Arabidopsis. Plant Cell 2008, 20, 48-58. [CrossRef]

20. McConnell, J.R.; Emery, J.; Eshed, Y.; Bao, N.; Bowman, J.; Barton, M.K. Role of PHABULOSA and PHAVOLUTA in determining radial patterning in shoots. Nature 2001, 411, 709-713. [CrossRef]

21. Emery, J.F.; Floyd, S.K.; Alvarez, J.; Eshed, Y.; Hawker, N.P.; Izhaki, A.; Baum, S.F.; Bowman, J.L. Radial patterning of Arabidopsis shoots by class III HD-ZIP and KANADI genes. Curr. Biol. 2003, 13, 1768-1774. [CrossRef] [PubMed]

22. Merelo, P.; Paredes, E.B.; Heisler, M.G.; Wenkel, S. The shady side of leaf development: The role of the REVOLUTA/KANADI1 module in leaf patterning and auxin-mediated growth promotion. Curr. Opin. Plant. Biol. 2017, 35, 111-116. [CrossRef] [PubMed]

23. Montgomery, T.A.; Howell, M.D.; Cuperus, J.T.; Li, D.; Hansen, J.E.; Alexander, A.L.; Chapman, E.J.; Fahlgren, N.; Allen, E.; Carrington, J.C. Specificity of ARGONAUTE7-miR390 interaction and dual functionality in TAS3 trans-acting siRNA formation. Cell 2008, 133, 128-141. [CrossRef] [PubMed]

24. Tatematsu, K.; Toyokura, K.; Miyashima, S.; Nakajima, K.; Okada, K. A molecular mechanism that confines the activity pattern of miR165 in Arabidopsis leaf primordia. Plant J. 2015, 82, 596-608. [CrossRef]

25. Kerstetter, R.A.; Bollman, K.; Taylor, R.A.; Bomblies, K.; Poethig, R.S. KANADI regulates organ polarity in Arabidopsis. Nature 2001, 411, 706-709. [CrossRef]

26. Sawa, S.; Ito, T.; Shimura, Y.; Okada, K. FILAMENTOUS FLOWER controls the formation and development of arabidopsis inflorescences and floral meristems. Plant Cell 1999, 11, 69-86. [CrossRef]

27. Siegfried, K.R.; Eshed, Y.; Baum, S.F.; Otsuga, D.; Drews, G.N.; Bowman, J.L. Members of the YABBY gene family specify abaxial cell fate in Arabidopsis. Development 1999, 126, 4117-4128.

28. Watanabe, K.; Okada, K. Two discrete cis elements control the Abaxial side-specific expression of the FILAMENTOUS FLOWER gene in Arabidopsis. Plant Cell 2003, 15, 2592-2602. [CrossRef] 
29. Golz, J.F.; Roccaro, M.; Kuzoff, R.; Hudson, A. GRAMINIFOLIA promotes growth and polarity of Antirrhinum leaves. Development 2004, 131, 3661-3670. [CrossRef]

30. Sarojam, R.; Sappl, P.G.; Goldshmidt, A.; Efroni, I.; Floyd, S.K.; Eshed, Y.; Bowman, J.L. Differentiating Arabidopsis shoots from leaves by combined YABBY activities. Plant Cell 2010, 22, 2113-2130. [CrossRef]

31. Sessions, A.; Nemhauser, J.L.; McColl, A.; Roe, J.L.; Feldmann, K.A.; Zambryski, P.C. ETTIN patterns the Arabidopsis floral meristem and reproductive organs. Development 1997, 124, 4481-4491. [PubMed]

32. Shi, J.; Dong, J.; Xue, J.; Wang, H.; Yang, Z.; Jiao, Y.; Xu, L.; Huang, H. Model for the role of auxin polar transport in patterning of the leaf adaxial-abaxial axis. Plant J. 2017, 92, 469-480. [CrossRef] [PubMed]

33. Phelps-Durr, T.L.; Thomas, J.; Vahab, P.; Timmermans, M.C. Maize rough sheath2 and its Arabidopsis orthologue ASYMMETRIC LEAVES1 interact with HIRA, a predicted histone chaperone, to maintain knox gene silencing and determinacy during organogenesis. Plant Cell 2005, 17, 2886-2898. [CrossRef] [PubMed]

34. Yang, J.Y.; Iwasaki, M.; Machida, C.; Machida, Y.; Zhou, X. Chua NH: BetaC1, the pathogenicity factor of TYLCCNV, interacts with AS1 to alter leaf development and suppress selective jasmonic acid responses. Genes Dev. 2008, 22, 2564-2577. [CrossRef]

35. Ueno, Y.; Ishikawa, T.; Watanabe, K.; Terakura, S.; Iwakawa, H.; Okada, K.; Machida, C.; Machida, Y. Histone deacetylases and ASYMMETRIC LEAVES2 are involved in the establishment of polarity in leaves of Arabidopsis. Plant Cell 2007, 19, 445-457. [CrossRef]

36. Luo, M.; Yu, C.W.; Chen, F.F.; Zhao, L.; Tian, G.; Liu, X.; Cui, Y.; Yang, J.Y.; Wu, K. Histone deacetylase HDA6 is functionally associated with AS1 in repression of KNOX genes in arabidopsis. PLoS Genet 2012, 8, e1003114. [CrossRef]

37. Iwakawa, H.; Iwasaki, M.; Kojima, S.; Ueno, Y.; Soma, T.; Tanaka, H.; Semiarti, E.; Machida, Y.; Machida, C. Expression of the ASYMMETRIC LEAVES2 gene in the adaxial domain of Arabidopsis leaves represses cell proliferation in this domain and is critical for the development of properly expanded leaves. Plant J. 2007, 51, 173-184. [CrossRef]

38. Shuai, B.; Reynaga-Peña, C.G.; Springer, P.S. The lateral organ boundaries gene defines a novel, plant-specific gene family. Plant. Physiol. 2002, 129, 747-761. [CrossRef]

39. Matsumura, Y.; Iwakawa, H.; Machida, Y.; Machida, C. Characterization of genes in the ASYMMETRIC LEAVES2/LATERAL ORGAN BOUNDARIES (AS2/LOB) family in Arabidopsis thaliana, and functional and molecular comparisons between AS2 and other family members. Plant J. 2009, 58, 525-537. [CrossRef]

40. Song, B.; Tang, Z.; Li, X.; Li, J.; Zhang, M.; Zhao, K.; Liu, H.; Zhang, S.; Wu, J. Mining and evolution analysis of lateral organ boundaries domain (LBD) genes in Chinese white pear (Pyrus bretschneideri). BMC Genom. 2020, 21, 644. [CrossRef]

41. Guo, B.J.; Wang, J.; Lin, S.; Tian, Z.; Zhou, K.; Luan, H.Y.; Lyu, C.; Zhang, X.Z.; Xu, R.G. A genome-wide analysis of the ASYMMETRIC LEAVES2/LATERAL ORGAN BOUNDARIES (AS2/LOB) gene family in barley (Hordeum vulgare L.). J. Zhejiang Univ. Sci. B 2016, 17, 763-774. [CrossRef] [PubMed]

42. Guo, Z.; Xu, H.; Lei, Q.; Du, J.; Li, C.; Wang, C.; Yang, Y.; Sun, X. The Arabidopsis transcription factor LBD15 mediates ABA signaling and tolerance of water-deficit stress by regulating ABI4 expression. Plant J. 2020. [CrossRef] [PubMed]

43. Zhang, Y.; Li, Z.; Ma, B.; Hou, Q.; Wan, X. Phylogeny and Functions of LOB Domain Proteins in Plants. Int. J. Mol. Sci. 2020, 21, 2278. [CrossRef] [PubMed]

44. Yu, J.; Xie, Q.; Li, C.; Dong, Y.; Zhu, S.; Chen, J. Comprehensive characterization and gene expression patterns of LBD gene family in Gossypium. Planta 2020, 251, 81. [CrossRef]

45. Liu, H.; Cao, M.; Chen, X.; Ye, M.; Zhao, P.; Nan, Y.; Li, W.; Zhang, C.; Kong, L.; Kong, N.; et al. Genome-Wide Analysis of the Lateral Organ Boundaries Domain (LBD) Gene Family in. Int. J. Mol. Sci. 2019, $20,5360$. [CrossRef]

46. Zhang, Z.; Zhao, H.; Li, W.; Wu, J.; Zhou, Z.; Zhou, F.; Chen, H.; Lin, Y. Genome-wide association study of callus induction variation to explore the callus formation mechanism of rice. J. Integr. Plant. Biol. 2019, 61, 1134-1150. [CrossRef]

47. Chen, W.F.; Wei, X.B.; Rety, S.; Huang, L.Y.; Liu, N.N.; Dou, S.X.; Xi, X.G. Structural analysis reveals a "molecular calipers" mechanism for a LATERAL ORGAN BOUNDARIES DOMAIN transcription factor protein from wheat. J. Biol. Chem. 2019, 294, 142-156. [CrossRef] 
48. Takahashi, H.; Iwakawa, H.; Nakao, S.; Ojio, T.; Morishita, R.; Morikawa, S.; Machida, Y.; Machida, C.; Kobayashi, T. Knowledge-based fuzzy adaptive resonance theory and its application to the analysis of gene expression in plants. J. Biosci. Bioeng. 2008, 106, 587-593. [CrossRef]

49. Iwasaki, M.; Takahashi, H.; Iwakawa, H.; Nakagawa, A.; Ishikawa, T.; Tanaka, H.; Matsumura, Y.; Pekker, I.; Eshed, Y.; Vial-Pradel, S.; et al. Dual regulation of ETTIN (ARF3) gene expression by AS1-AS2, which maintains the DNA methylation level, is involved in stabilization of leaf adaxial-abaxial partitioning in Arabidopsis. Development 2013, 140, 1958-1969. [CrossRef]

50. Husbands, A.Y.; Benkovics, A.H.; Nogueira, F.T.; Lodha, M.; Timmermans, M.C. The ASYMMETRIC LEAVES Complex Employs Multiple Modes of Regulation to Affect Adaxial-Abaxial Patterning and Leaf Complexity. Plant Cell 2015, 27, 3321-3335. [CrossRef]

51. Hunter, C.; Willmann, M.R.; Wu, G.; Yoshikawa, M.; de la Luz Gutiérrez-Nava, M.; Poethig, S.R. Trans-acting siRNA-mediated repression of ETTIN and ARF4 regulates heteroblasty in Arabidopsis. Development 2006, 133, 2973-2981. [CrossRef] [PubMed]

52. Luong, T.Q.; Keta, S.; Asai, T.; Kojima, S.; Nakagawa, A.; Micol, J.L.; Xia, S.; Machida, Y.; Machida, C. A genetic link between epigenetic repressor AS1-AS2 and DNA replication factors in establishment of adaxial-abaxial leaf polarity of Arabidopsis. Plant. Biotechnol. 2018, 35, 39-49. [CrossRef] [PubMed]

53. Pinon, V.; Etchells, J.P.; Rossignol, P.; Collier, S.A.; Arroyo, J.M.; Martienssen, R.A.; Byrne, M.E. Three PIGGYBACK genes that specifically influence leaf patterning encode ribosomal proteins. Development 2008, 135, 1315-1324. [CrossRef] [PubMed]

54. Yao, Y.; Ling, Q.; Wang, H.; Huang, H. Ribosomal proteins promote leaf adaxial identity. Development 2008, 135, 1325-1334. [CrossRef]

55. Szakonyi, D.; Byrne, M.E. Ribosomal protein L27a is required for growth and patterning in Arabidopsis thaliana. Plant J. 2011, 65, 269-281. [CrossRef]

56. Horiguchi, G.; Mollá-Morales, A.; Pérez-Pérez, J.M.; Kojima, K.; Robles, P.; Ponce, M.R.; Micol, J.L.; Tsukaya, H. Differential contributions of ribosomal protein genes to Arabidopsis thaliana leaf development. Plant J. 2011, 65, 724-736. [CrossRef]

57. Casanova-Sáez, R.; Candela, H.; Micol, J.L. Combined haploinsufficiency and purifying selection drive retention of RPL36a paralogs in Arabidopsis. Sci. Rep. 2014, 4, 4122. [CrossRef]

58. Kojima, K.; Tamura, J.; Chiba, H.; Fukada, K.; Tsukaya, H.; Horiguchi, G. Two Nucleolar Proteins, GDP1 and OLI2, Function as Ribosome Biogenesis Factors and Are Preferentially Involved in Promotion of Leaf Cell Proliferation without Strongly Affecting Leaf Adaxial-Abaxial Patterning in Arabidopsis thaliana. Front. Plant Sci. 2017, 8, 2240. [CrossRef]

59. Matsumura, Y.; Ohbayashi, I.; Takahashi, H.; Kojima, S.; Ishibashi, N.; Keta, S.; Nakagawa, A.; Hayashi, R.; Saéz-Vásquez, J.; Echeverria, M.; et al. A genetic link between epigenetic repressor AS1-AS2 and a putative small subunit processome in leaf polarity establishment of Arabidopsis. Biol. Open 2016, 5, 942-954. [CrossRef]

60. Ohbayashi, I.; Konishi, M.; Ebine, K.; Sugiyama, M. Genetic identification of Arabidopsis RID2 as an essential factor involved in pre-rRNA processing. Plant J. 2011, 67, 49-60. [CrossRef]

61. Pontvianne, F.; Matía, I.; Douet, J.; Tourmente, S.; Medina, F.J.; Echeverria, M.; Sáez-Vásquez, J. Characterization of AtNUC-L1 reveals a central role of nucleolin in nucleolus organization and silencing of AtNUC-L2 gene in Arabidopsis. Mol. Biol. Cell 2007, 18, 369-379. [CrossRef] [PubMed]

62. Sáez-Vásquez, J.; Delseny, M. Ribosome Biogenesis in Plants: From Functional 45S Ribosomal DNA Organization to Ribosome Assembly Factors. Plant Cell 2019, 31, 1945-1967. [CrossRef] [PubMed]

63. Abbasi, N.; Kim, H.B.; Park, N.I.; Kim, H.S.; Kim, Y.K.; Park, Y.I.; Choi, S.B. APUM23, a nucleolar Puf domain protein, is involved in pre-ribosomal RNA processing and normal growth patterning in Arabidopsis. Plant J. 2010, 64, 960-976. [CrossRef] [PubMed]

64. Takahashi, H.; Iwakawa, H.; Ishibashi, N.; Kojima, S.; Matsumura, Y.; Prananingrum, P.; Iwasaki, M.; Takahashi, A.; Ikezaki, M.; Luo, L.; et al. Meta-analyses of microarrays of Arabidopsis asymmetric leaves1 (as1), as2 and their modifying mutants reveal a critical role for the ETT pathway in stabilization of adaxial-abaxial patterning and cell division during leaf development. Plant Cell Physiol. 2013, 54, 418-431. [CrossRef] [PubMed] 
65. Vial-Pradel, S.; Keta, S.; Nomoto, M.; Luo, L.; Takahashi, H.; Suzuki, M.; Yokoyama, Y.; Sasabe, M.; Kojima, S.; Tada, Y.; et al. Arabidopsis Zinc-Finger-Like Protein ASYMMETRIC LEAVES2 (AS2) and Two Nucleolar Proteins Maintain Gene Body DNA Methylation in the Leaf Polarity Gene ETTIN (ARF3). Plant Cell Physiol. 2018, 59, 1385-1397. [CrossRef]

66. Feric, M.; Vaidya, N.; Harmon, T.S.; Mitrea, D.M.; Zhu, L.; Richardson, T.M.; Kriwacki, R.W.; Pappu, R.V.; Brangwynne, C.P. Coexisting Liquid Phases Underlie Nucleolar Subcompartments. Cell 2016, 165, 1686-1697. [CrossRef]

67. Pontvianne, F.; Carpentier, M.C.; Durut, N.; Pavlištová, V.; Jaške, K.; Schořová, Š.; Parrinello, H.; Rohmer, M.; Pikaard, C.S.; Fojtová, M.; et al. Identification of Nucleolus-Associated Chromatin Domains Reveals a Role for the Nucleolus in 3D Organization of the A. thaliana Genome. Cell Rep. 2016, 16, 1574-1587. [CrossRef]

68. Bersaglieri, C.; Santoro, R. Genome Organization in and around the Nucleolus. Cells 2019, 8, 579. [CrossRef]

69. Ginisty, H.; Sicard, H.; Roger, B.; Bouvet, P. Structure and functions of nucleolin. J. Cell Sci. 1999, 112 Pt 6, 761-772.

70. Kojima, H.; Suzuki, T.; Kato, T.; Enomoto, K.; Sato, S.; Tabata, S.; Sáez-Vasquez, J.; Echeverría, M.; Nakagawa, T.; Ishiguro, S.; et al. Sugar-inducible expression of the nucleolin-1 gene of Arabidopsis thaliana and its role in ribosome synthesis, growth and development. Plant J. 2007, 49, 1053-1063. [CrossRef]

71. Petricka, J.J.; Nelson, T.M. Arabidopsis nucleolin affects plant development and patterning. Plant Physiol. 2007, 144, 173-186. [CrossRef] [PubMed]

72. Micol-Ponce, R.; Sarmiento-Mañús, R.; Ruiz-Bayón, A.; Montacié, C.; Sáez-Vasquez, J.; Ponce, M.R. Arabidopsis RIBOSOMAL RNA PROCESSING7 Is Required for $18 \mathrm{~S}$ rRNA Maturation. Plant Cell 2018, 30, 2855-2872. [CrossRef] [PubMed]

73. Durut, N.; Sáez-Vásquez, J. Nucleolin: Dual roles in rDNA chromatin transcription. Gene 2015, 556, 7-12. [CrossRef] [PubMed]

74. Montacié, C.; Durut, N.; Opsomer, A.; Palm, D.; Comella, P.; Picart, C.; Carpentier, M.C.; Pontvianne, F.; Carapito, C.; Schleiff, E.; et al. Nucleolar Proteome Analysis and Proteasomal Activity Assays Reveal a Link between Nucleolus and 26S Proteasome in. Front. Plant Sci. 2017, 8, 1815. [CrossRef]

75. Picart, C.; Pontvianne, F. Plant nucleolar DNA: Green light shed on the role of Nucleolin in genome organization. Nucleus 2017, 8, 11-16. [CrossRef]

76. Turner, A.J.; Knox, A.A.; Prieto, J.L.; McStay, B.; Watkins, N.J. A novel small-subunit processome assembly intermediate that contains the U3 snoRNP, nucleolin, RRP5, and DBP4. Mol. Cell Biol. 2009, 29, 3007-3017. [CrossRef]

77. Phipps, K.R.; Charette, J.; Baserga, S.J. The small subunit processome in ribosome biogenesis—Progress and prospects. Wiley Interdiscip Rev. RNA 2011, 2, 1-21. [CrossRef]

78. Granneman, S.; Bernstein, K.A.; Bleichert, F.; Baserga, S.J. Comprehensive mutational analysis of yeast DEXD/H box RNA helicases required for small ribosomal subunit synthesis. Mol. Cell Biol. 2006, 26, 1183-1194. [CrossRef]

79. Dragon, F.; Gallagher, J.E.; Compagnone-Post, P.A.; Mitchell, B.M.; Porwancher, K.A.; Wehner, K.A.; Wormsley, S.; Settlage, R.E.; Shabanowitz, J.; Osheim, Y.; et al. A large nucleolar U3 ribonucleoprotein required for $18 \mathrm{~S}$ ribosomal RNA biogenesis. Nature 2002, 417, 967-970. [CrossRef]

80. Feng, J.M.; Tian, H.F.; Wen, J.F. Origin and evolution of the eukaryotic SSU processome revealed by a comprehensive genomic analysis and implications for the origin of the nucleolus. Genome Biol. Evol. 2013, 5, 2255-2267. [CrossRef]

81. You, K.T.; Park, J.; Kim, V.N. Role of the small subunit processome in the maintenance of pluripotent stem cells. Genes Dev. 2015, 29, 2004-2009. [CrossRef]

82. Sardana, R.; White, J.P.; Johnson, A.W. The rRNA methyltransferase Bud23 shows functional interaction with components of the SSU processome and RNase MRP. RNA 2013, 19, 828-840. [CrossRef] [PubMed]

83. Sardana, R.; Zhu, J.; Gill, M.; Johnson, A.W. Physical and functional interaction between the methyltransferase Bud23 and the essential DEAH-box RNA helicase Ecm16. Mol. Cell Biol. 2014, 34, 2208-2220. [CrossRef] [PubMed]

84. Zhu, J.; Liu, X.; Anjos, M.; Correll, C.C.; Johnson, A.W. Utp14 Recruits and Activates the RNA Helicase Dhr1 to Undock U3 snoRNA from the Preribosome. Mol. Cell Biol. 2016, 36, 965-978. [CrossRef] [PubMed] 
85. Ohbayashi, I.; Lin, C.Y.; Shinohara, N.; Matsumura, Y.; Machida, Y.; Horiguchi, G.; Tsukaya, H.; Sugiyama, M. Evidence for a Role of ANAC082 as a Ribosomal Stress Response Mediator Leading to Growth Defects and Developmental Alterations in Arabidopsis. Plant Cell 2017, 29, 2644-2660. [CrossRef]

86. Ohbayashi, I.; Sugiyama, M. Plant Nucleolar Stress Response, a New Face in the NAC-Dependent Cellular Stress Responses. Front. Plant Sci. 2017, 8, 2247. [CrossRef]

87. Huang, K.C.; Lin, W.C.; Cheng, W.H. Salt hypersensitive mutant 9, a nucleolar APUM23 protein, is essential for salt sensitivity in association with the ABA signaling pathway in Arabidopsis. BMC Plant Biol. 2018, 18, 40. [CrossRef]

88. Bernstein, K.A.; Gallagher, J.E.; Mitchell, B.M.; Granneman, S.; Baserga, S.J. The small-subunit processome is a ribosome assembly intermediate. Eukaryot. Cell 2004, 3, 1619-1626. [CrossRef]

89. McCann, K.L.; Charette, J.M.; Vincent, N.G.; Baserga, S.J. A protein interaction map of the LSU processome. Genes Dev. 2015, 29, 862-875. [CrossRef]

90. Lawrence, R.J.; Earley, K.; Pontes, O.; Silva, M.; Chen, Z.J.; Neves, N.; Viegas, W.; Pikaard, C.S. A concerted DNA methylation/histone methylation switch regulates rRNA gene dosage control and nucleolar dominance. Mol. Cell 2004, 13, 599-609. [CrossRef]

91. Pontes, O.; Lawrence, R.J.; Silva, M.; Preuss, S.; Costa-Nunes, P.; Earley, K.; Neves, N.; Viegas, W.; Pikaard, C.S. Postembryonic establishment of megabase-scale gene silencing in nucleolar dominance. PLoS ONE 2007, 2, e1157. [CrossRef]

92. Zhou, C.; Labbe, H.; Sridha, S.; Wang, L.; Tian, L.; Latoszek-Green, M.; Yang, Z.; Brown, D.; Miki, B.; Wu, K. Expression and function of HD2-type histone deacetylases in Arabidopsis development. Plant J. 2004, 38, 715-724. [CrossRef] [PubMed]

93. Luo, L.; Ando, S.; Sasabe, M.; Machida, C.; Kurihara, D.; Higashiyama, T.; Machida, Y. Arabidopsis ASYMMETRIC LEAVES2 protein required for leaf morphogenesis consistently forms speckles during mitosis of tobacco BY-2 cells via signals in its specific sequence. J. Plant Res. 2012, 125, 661-668. [CrossRef] [PubMed]

94. Luo, L.; Ando, S.; Sakamoto, Y.; Suzuki, T.; Takahashi, H.; Ishibashi, N.; Kojima, S.; Kurihara, D.; Higashiyama, T.; Yamamoto, K.T.; et al. The formation of perinucleolar bodies is important for normal leaf development and requires the zinc-finger DNA-binding motif in Arabidopsis ASYMMETRIC LEAVES2. Plant J. 2020, 101, 1118-1134. [CrossRef] [PubMed]

95. Song, Z.; Wu, M. Identification of a novel nucleolar localization signal and a degradation signal in Survivin-deltaEx3: A potential link between nucleolus and protein degradation. Oncogene 2005, 24, 2723-2734. [CrossRef] [PubMed]

96. Musinova, Y.R.; Lisitsyna, O.M.; Golyshev, S.A.; Tuzhikov, A.I.; Polyakov, V.Y.; Sheval, E.V. Nucleolar localization/retention signal is responsible for transient accumulation of histone $\mathrm{H} 2 \mathrm{~B}$ in the nucleolus through electrostatic interactions. Biochim. Biophys. Acta 2011, 1813, 27-38. [CrossRef] [PubMed]

97. de Melo, I.S.; Jimenez-Nuñez, M.D.; Iglesias, C.; Campos-Caro, A.; Moreno-Sanchez, D.; Ruiz, F.A.; Bolívar, J. NOA36 protein contains a highly conserved nucleolar localization signal capable of directing functional proteins to the nucleolus, in mammalian cells. PLoS ONE 2013, 8, e59065. [CrossRef]

98. Earley, L.F.; Kawano, Y.; Adachi, K.; Sun, X.X.; Dai, M.S.; Nakai, H. Identification and characterization of nuclear and nucleolar localization signals in the adeno-associated virus serotype 2 assembly-activating protein. J. Virol. 2015, 89, 3038-3048. [CrossRef]

99. Ye, J.; Yang, J.; Sun, Y.; Zhao, P.; Gao, S.; Jung, C.; Qu, J.; Fang, R.; Chua, N.H. Geminivirus Activates ASYMMETRIC LEAVES 2 to Accelerate Cytoplasmic DCP2-Mediated mRNA Turnover and Weakens RNA Silencing in Arabidopsis. PLoS Pathog. 2015, 11, e1005196. [CrossRef]

100. Vial-Pradel, S.; Hasegawa, Y.; Nakagawa, A.; Miyaki, S.; Machida, Y.; Kojima, S.; Machida, C.; Takahashi, H. SIMON: Simple methods for analyzing DNA methylation by targeted bisulfite next-generation sequencing. Plant. Biotechnol. 2019, 36, 213-222. [CrossRef]

101. Husbands, A.; Bell, E.M.; Shuai, B.; Smith, H.M.; Springer, P.S. LATERAL ORGAN BOUNDARIES defines a new family of DNA-binding transcription factors and can interact with specific bHLH proteins. Nucleic Acids Res. 2007, 35, 6663-6671. [CrossRef] [PubMed]

102. Ohashi-Ito, K.; Iwamoto, K.; Fukuda, H. LOB DOMAIN-CONTAINING PROTEIN 15 Positively Regulates Expression of VND7, a Master Regulator of Tracheary Elements. Plant Cell Physiol. 2018, 59, 989-996. [CrossRef] [PubMed] 
103. Nishimura, T. Gene Body Methylation Involved in Leaf Development. Plant Cell Physiol. 2018, 59, 1288-1289. [CrossRef] [PubMed]

104. Lyko, F. The DNA methyltransferase family: A versatile toolkit for epigenetic regulation. Nat. Rev. Genet. 2018, 19, 81-92. [CrossRef]

105. Song, J.; Rechkoblit, O.; Bestor, T.H.; Patel, D.J. Structure of DNMT1-DNA complex reveals a role for autoinhibition in maintenance DNA methylation. Science 2011, 331, 1036-1040. [CrossRef]

106. Long, H.K.; Blackledge, N.P.; Klose, R.J. ZF-CxxC domain-containing proteins, CpG islands and the chromatin connection. Biochem. Soc. Trans. 2013, 41, 727-740. [CrossRef]

107. Nishiyama, A.; Yamaguchi, L.; Sharif, J.; Johmura, Y.; Kawamura, T.; Nakanishi, K.; Shimamura, S.; Arita, K.; Kodama, T.; Ishikawa, F.; et al. Uhrf1-dependent H3K23 ubiquitylation couples maintenance DNA methylation and replication. Nature 2013, 502, 249-253. [CrossRef]

108. Song, J.; Du, Z.; Ravasz, M.; Dong, B.; Wang, Z.; Ewing, R.M. A Protein Interaction between $\beta$-Catenin and Dnmt1 Regulates Wnt Signaling and DNA Methylation in Colorectal Cancer Cells. Mol. Cancer Res. 2015, 13, 969-981. [CrossRef]

109. Zhang, Z.M.; Liu, S.; Lin, K.; Luo, Y.; Perry, J.J.; Wang, Y.; Song, J. Crystal Structure of Human DNA Methyltransferase 1. J. Mol. Biol. 2015, 427, 2520-2531. [CrossRef]

110. Du, J. Structure and Mechanism of Plant DNA Methyltransferases. Adv. Exp. Med. Biol. 2016, 945, $173-192$. [CrossRef]

111. Ferry, L.; Fournier, A.; Tsusaka, T.; Adelmant, G.; Shimazu, T.; Matano, S.; Kirsh, O.; Amouroux, R.; Dohmae, N.; Suzuki, T.; et al. Methylation of DNA Ligase 1 by G9a/GLP Recruits UHRF1 to Replicating DNA and Regulates DNA Methylation. Mol. Cell 2017, 67, 550-565.e555. [CrossRef] [PubMed]

112. Ryazanova, A.Y.; Abrosimova, L.A.; Oretskaya, T.S.; Kubareva, E.A. Diverse Domains of (Cytosine-5)-DNA Methyltransferases: Structural and Functional Characterization, Methylation-From DNA, RNA and Histones to Diseases and Treatment; Dricu, A., Ed.; InTech: Rijeka, Croatia, 2012; pp. $29-69$.

113. Pontvianne, F.; Abou-Ellail, M.; Douet, J.; Comella, P.; Matia, I.; Chandrasekhara, C.; Debures, A.; Blevins, T.; Cooke, R.; Medina, F.J.; et al. Nucleolin is required for DNA methylation state and the expression of rRNA gene variants in Arabidopsis thaliana. PLoS Genet 2010, 6, e1001225. [CrossRef] [PubMed]

114. Pontvianne, F.; Blevins, T.; Chandrasekhara, C.; Mozgová, I.; Hassel, C.; Pontes, O.M.; Tucker, S.; Mokros, P.; Muchová, V.; Fajkus, J.; et al. Subnuclear partitioning of rRNA genes between the nucleolus and nucleoplasm reflects alternative epiallelic states. Genes Dev. 2013, 27, 1545-1550. [CrossRef] [PubMed]

115. To, T.K.; Kim, J.M.; Matsui, A.; Kurihara, Y.; Morosawa, T.; Ishida, J.; Tanaka, M.; Endo, T.; Kakutani, T.; Toyoda, T.; et al. Arabidopsis HDA6 regulates locus-directed heterochromatin silencing in cooperation with MET1. PLoS Genet 2011, 7, e1002055. [CrossRef]

116. Liu, X.; Yu, C.W.; Duan, J.; Luo, M.; Wang, K.; Tian, G.; Cui, Y.; Wu, K. HDA6 directly interacts with DNA methyltransferase MET1 and maintains transposable element silencing in Arabidopsis. Plant Physiol. 2012, 158, 119-129. [CrossRef]

117. Lodha, M.; Marco, C.F.; Timmermans, M.C. The ASYMMETRIC LEAVES complex maintains repression of KNOX homeobox genes via direct recruitment of Polycomb-repressive complex2. Genes Dev. 2013, 27, 596-601. [CrossRef]

118. Li, Z.; Li, B.; Liu, J.; Guo, Z.; Liu, Y.; Li, Y.; Shen, W.H.; Huang, Y.; Huang, H.; Zhang, Y.; et al. Transcription factors AS1 and AS2 interact with LHP1 to repress KNOX genes in Arabidopsis. J. Integr. Plant Biol. 2016, 58, 959-970. [CrossRef]

119. Lin, X.; Gu, D.; Zhao, H.; Peng, Y.; Zhang, G.; Yuan, T.; Li, M.; Wang, Z.; Wang, X.; Cui, S. LFR is functionally associated with AS2 to mediate leaf development in Arabidopsis. Plant J. 2018, 95, 598-612. [CrossRef]

120. Xu, C.; Luo, F.; Hochholdinger, F. LOB Domain Proteins: Beyond Lateral Organ Boundaries. Trends Plant Sci. 2016, 21, 159-167. [CrossRef]

121. Kim, M.J.; Kim, J. Identification of nuclear localization signal in ASYMMETRIC LEAVES2-LIKE18/LATERAL ORGAN BOUNDARIES DOMAIN16 (ASL18/LBD16) from Arabidopsis. J. Plant Physiol. 2012, 169, 1221-1226. [CrossRef]

122. Correll, C.C.; Bartek, J.; Dundr, M. The Nucleolus: A Multiphase Condensate Balancing Ribosome Synthesis and Translational Capacity in Health, Aging and Ribosomopathies. Cells 2019, 8, 869. [CrossRef] [PubMed] 
123. Nishimura, K.; Kumazawa, T.; Kuroda, T.; Katagiri, N.; Tsuchiya, M.; Goto, N.; Furumai, R.; Murayama, A.; Yanagisawa, J.; Kimura, K. Perturbation of ribosome biogenesis drives cells into senescence through $5 \mathrm{~S}$ RNP-mediated p53 activation. Cell Rep. 2015, 10, 1310-1323. [CrossRef] [PubMed]

124. Padeken, J.; Heun, P. Nucleolus and nuclear periphery: Velcro for heterochromatin. Curr. Opin. Cell Biol. 2014, 28, 54-60. [CrossRef] [PubMed]

125. Carpentier, M.C.; Picart-Picolo, A.; Pontvianne, F. A Method to Identify Nucleolus-Associated Chromatin Domains (NADs). Methods Mol. Biol. 2018, 1675, 99-109. [CrossRef] [PubMed]

126. Chandrasekhara, C.; Mohannath, G.; Blevins, T.; Pontvianne, F.; Pikaard, C.S. Chromosome-specific NOR inactivation explains selective rRNA gene silencing and dosage control in Arabidopsis. Genes Dev. 2016, 30, 177-190. [CrossRef] [PubMed]

127. Mohannath, G.; Pontvianne, F.; Pikaard, C.S. Selective nucleolus organizer inactivation in Arabidopsis is a chromosome position-effect phenomenon. Proc. Natl. Acad. Sci. USA 2016, 113, 13426-13431. [CrossRef] [PubMed]

128. Pavlištová, V.; Dvořáčková, M.; Jež, M.; Mozgová, I.; Mokroš, P.; Fajkus, J. Phenotypic reversion in fas mutants of Arabidopsis thaliana by reintroduction of FAS genes: Variable recovery of telomeres with major spatial rearrangements and transcriptional reprogramming of 45S rDNA genes. Plant J. 2016, 88, 411-424. [CrossRef]

129. O'Malley, R.C.; Huang, S.C.; Song, L.; Lewsey, M.G.; Bartlett, A.; Nery, J.R.; Galli, M.; Gallavotti, A.; Ecker, J.R. Cistrome and Epicistrome Features Shape the Regulatory DNA Landscape. Cell 2016, 165, 1280-1292. [CrossRef]

(C) 2020 by the authors. Licensee MDPI, Basel, Switzerland. This article is an open access article distributed under the terms and conditions of the Creative Commons Attribution (CC BY) license (http://creativecommons.org/licenses/by/4.0/). 